Anna KUCHARSKA

Uniwersytet Warszawski

\title{
Kościół Jezusa Chrystusa Świętych w Dniach Ostatnich w Polsce
}

\begin{abstract}
Czy Polska jest krajem otwartym na nowe religie? Odpowiedź na to pytanie jest złożona. Z punktu widzenia prawa każde wyznanie czy religia mają zagwarantowaną równość. Biorąc jednak pod uwagę fakt, iż 90\% Polaków (taka jest przynajmniej prawda statystyczna) jest wyznania rzymskokatolickiego, należy zauważyć, że katolicyzm jest zdecydowanie dominującą religią, a pozostałe wyznania nie cieszą się popularnością. Sięgający swoją historią do roku 966, katolicyzm stał się na przestrzeni wieków częścią kultury polskiej. Mimo podziałów, jakie Kościół ten przeszedł na Zachodzie, w Polsce pozostał dosyć jednorodny. Jednakże jego silna pozycja nie przeszkodziła przedstawicielom innych wyznań w docieraniu na tereny Polski i pozyskiwaniu współwyznawców.

Ewangelizacja jest również jedną z głównych zasad funkcjonowania Kościoła Jezusa Chrystusa Świętych w Dniach Ostatnich, popularnie zwanego Kościołem Mormonów. Członkowie Kościoła od początku jego założenia w 1830 roku kładli nacisk na docieranie do tych zakątków, gdzie ich wiara nie była jeszcze znana w myśl ostatniego przykazania wydanego przez Jezusa Chrystusa, w którym nakazuje on swoim uczniom, aby nauczali „wszystkie narody, udzielając im chrztu w imię Ojca i Syna, i Ducha Świętego"1. Początkowo celem misjonarzy był obszar USA, gdzie ta religia się narodziła, następnie z powodu bliskiego sąsiedztwa - Kanada, a w dalszej kolejności Anglia².
\end{abstract}

1 Pismo Święte Nowego Testamentu. Ewangelia wg Św. Mateusza 28:19. „Idźcie więc i nauczajcie wszystkie narody, udzielając im chrztu w imię Ojca i Syna, i Ducha Świętego. Uczcie je zachowywać wszystko, co wam przykazałem”. Również wg jednego z przypuszczalnych objawień Joseph'a Smith'a członkowie Kościoła powinni zanieść Słowo Boże aż na krańce świata. Doctrines and Covenants 112:4, http://scriptures.lds.org/en/dc/112/4a.

2 Praca misjonarska na terenie USA wśród rdzennych mieszkańców tego kraju rozpoczęła się w 1830 roku, a wśród obywateli tego kraju w 1831 r. zaraz po przybyciu członków Kościoła do Ohio. Do Kanady rozpoczęto wysyłać misjonarzy w 1836, a do 
Obecnie na świecie służy około 60000 misjonarzy $^{3}$. Są to młodzi ludzie, którzy zaczynają swoją służbę misjonarską najczęściej między 19 a 21 rokiem życia. Ich praca jest całkowicie dobrowolna oraz bezpłatna. Przed wyruszeniem na misje sami uczestnicy muszą zarobić na swoje utrzymanie w kraju, do którego zostaną wysłani, o czym decyduje Prezydent Kościoła ${ }^{4}$. Ich praca polega na powiadamianiu ludzi o ich wierze oraz zachęcaniu do uczestnictwa $\mathrm{w}$ ich spotkaniach tudzież bezpłatnych kursach języka angielskiego ${ }^{5}$. Praca misjonarzy okazała się tak efektywna, że w ciagu ponad 170 lat istnienia tej religii do Kościoła przyłączyło się około dwanaście milionów wiernych, z czego około połowa tzn. 5,5 miliona w USA ${ }^{6}$. Tym samym Kościół Jezusa Chrystusa Świętych w Dniach Ostatnich stał się jedną z największych denominacji w tym kraju. Nie oznacza to oczywiście, że praca misjonarska przestała być priorytetem Kościoła w pozyskiwaniu nowych członków. Wręcz przeciwnie. W dalszym ciągu Kościół rozwija się bardzo dynamicznie. Obecnie wskaźnik wzrostu wynosi 1,71\% rocznie, co przy tegorocznej liczbie wyznawców daje nam liczbę 9405 osób $^{7}$. Dlaczego członkowie Kościoła z taką determinacją nawracają nowych członków? Wyjaśnia to John Taylor - Prezydent Kościoła w latach 1880-1887, który mówi, że misjonarze mają przygotować wszystkie kraje na przyjście Chrystusa, który założy swoje Królestwo, któremu poddadzą się wszystkie narody ${ }^{8}$.

Anglii w 1837 roku. Do 1837 roku ochrzczono 16 tysięcy osób w Wielkiej Brytanii, Wyspach Foxa oraz Górnej Kanadzie. J. Allen, G. Leonard, The Story of the Latter-day Saints, Salt Lake City 1992, s. 62-63, 82-83, 125, 127.

3 Oficjalna strona internetowa Kościoła Jezusa Chrystusa Świętych w Dniach Ostatnich: http://www.mormon.org/learn/0,8672,1022-1,00.html.

4 Obecnie Prezydentem Kościoła Jezusa Świętych w Dniach Ostatnich jest Gordon B. Hinckley.

5 Interesująca może być również inna technika werbowania nowych członków Kościoła często stosowana w latach 60-tych XX wieku tzw. ,baseball baptisms”. Polegała ona na chrzczeniu ludzi, którzy nie byli w pełni poinformowani o szczegółach wiary Kościoła Jezusa Chrystusa Świętych w Dniach Ostatnich. W zamian za chrzest obiecywano korzyści np. szansę zostania członkiem drużyny sportowej. Allen, Leonard, s. 610.

${ }^{6}$ Oficjalna strona internetowa National Council of Churches USA: http://www.ncccusa.org/news/050330yearbook.html.

7 „Mormons Atop Growth List”, 26 luty 2005, The Charlotte Observer, http://www.rickross.com/reference/mormon/mormon226.html.

8 John Taylor, January 18, 1865, Remarks By Elder John Taylor Different Ideas of Nations in Regard to Government-Views of the Latter-Day Saints: Their Philanthro- 
Należy zadać pytanie, dlaczego religia Kościoła Jezusa Chrystusa Świętych w Dniach Ostatnich była i w dalszym ciąu jest tak atrakcyjna. Po pierwsze, dawała ona poczucie bezpieczeństwa oraz nadziei na lepszą przyszłość. Przybliżała ludziom Boga poprzez stwierdzenie, że był on kiedyś tak jak my człowiekiem oraz dostąpił stanu boskości poprzez życie zgodne z przykazaniami boskimi. Mormonizm wypływający z tradycji Drugiego Wielkiego Przebudzenia opartego na wartościach arminianizmu podkreślał również indywidualną rolę człowieka w drodze do zbawienia9 Sprzeciwiał się tym samym predestynacji - powszechnie przyjętej koncepcji kalwinistycznej, według której zbawienie zależało wyłącznie od woli boskiej.

Po drugie, o atrakcyjności Kościoła decydowała jego zdolność do modyfikacji swoich praktyk i wierzeń dzięki ciągłej rzekomej możliwości kontaktowania się z Bogiem poprzez osobę Prezydenta Kościoła zwanego również prorokiem. Otóż okazuje się, że pomimo zapewnień władz Kościoła o ich niezmienności, religia ta ewoluowała w taki sposób, aby dostosować się do ducha czasów obowiązującego w danym okresie. Należy jednak zaznaczyć, iż mimo tych zmian i dostosowań religia ta rozwijała się początkowo dosyć wolno. Dlaczego? Danny Jorgensen, socjolog religii, twierdzi, że aby przetrwać nowa religia musi zaoferować sensowną alternatywę już istniejącym religiom. Jeśli nowości wprowadzane do danej religii nie będą szły w parze $\mathrm{z}$ tradycjami danego społeczeństwa, to będzie ona uważana za nieatrakcyjną, a nawet odbiegającą od przyjętych norm ${ }^{10}$. Tak stało się w przypadku Kościoła Jezusa Chrystusa Świętych w Dniach Ostatnich. W początkowej fazie tworzenia się tej religii członkowie Kościoła byli oskarżani o szerzenie związków poligamicznych, naruszanie

py-Reformation Effected By Them-Liberty of Conscience Allowed to, „Journal of Discourses", vol. 11, http://search.ldslibrary.com/719707.

9 Arminianizm to szkoła myśli teologicznej założona przez holenderskiego teologa Jakuba Arminiusa żyjącego w latach 1560-1609. Głównym jego wkładem w rozwój myśli teologicznej było odrzucenie całkowitej deprawacji człowieka oraz zaprzeczenie idei ograniczonego udziału człowieka w boskim planie zbawienia. Tym samym sprzeciwił się on doktrynom głoszonym przez Jana Kalwina (1509-1564), francuskiego humanistę oraz propagatora Ruchu Reformacji, który podkreślał bezwarunkową predestynację oraz możliwość zbawienia jedynie dla ograniczonej liczby ludzi. S. Ahlstrom, A Religious History of the American People, New Haven-London 2004, s. 77,404 .

${ }^{10}$ D. Jorgensen, The Latter-day Saint (Mormon) Religion in America and the World, w: World Religions in America, ed. J. Neusner, Westminster 2000, s. 206. 
wartości judeochrześcijańskich, próbę utworzenia teokracji w państwie, które otwarcie głosiło rozdział instytucji kościelnych i państwowych, spekulacje ziemią oraz poprzez otwieranie konkurencyjnych firm odbieranie dochodów lokalnym mieszkańcom. Takie często nie bezpodstawne oskarżenia $\mathrm{w}$ połączeniu $\mathrm{z}$ religijnymi innowacjami wprowadzanymi przez Joseph'a Smith'a i jego następców takimi jak wielobóstwo czy człowieczeństwo Boga powodowały, że Mormoni musieli przenosić się z miejsca na miejsce, nie będąc zaakceptowanymi przez szersze kręgi społeczeństwa. Jednakże to, co było przedmiotem pośmiewiska lub nawet pogardy, dla reszty społeczeństwa było doskonałym elementem scalającym nową wspólnotę religijną oraz przyciagającym nowych wiernych spragnionych poczucia przynależności, nadziei na lepszą przyszłość oraz wiary w możliwość ich własnego udziału w procesie zbawienia.

W pierwszych latach swojego istnienia, tzn. od 1830 do 1904 roku, liczba członków Kościoła wzrosła do ok. 268 300. Po 1904 roku, kiedy to ostatecznie Mormoni znieśli poligamię, a przez to uznali nadrzędną pozycję władzy USA, nastąpił prawdziwy boom we wzroście liczby członków tego Kościoła. Było to poparte ich zaangażowaniem w życie społeczne oraz gospodarcze USA. W 1950 roku liczba członków wzrosła do około jednego miliona. Jednakże w tym roku Mormonizm mógł być wciąż uważany za religię jedynie amerykańską, gdyż tylko 7,7\% członków Kościoła mieszkało poza granicami USA. Dopiero po roku 1978, kiedy to Prezydent Kościoła - Spencer Kimball - pod wpływem rzekomego objawienia, a w rzeczywistości pod presją opinii publicznej popierającej Civil Rights Movement zniósł zakaz chrzczenia oraz wyświęcania na kapłanów osób o czarnym kolorze skóry, zanotowano kolejny duży wzrost członków Kościoła. Wyżej wspomniane objawienie jak również wejście ludzkości w erę wynalazków takich jak telefony, telewizory czy samoloty umożliwiły dotarcie do krajów niedostępnych dotąd dla tej religii na kontynentach Ameryki Południowej i Środkowej, a także Afryki i Europy ${ }^{11}$.

11 Wszystkie liczby użyte w tym paragrafie pochodzą z książki: J. Allen, G. Leonard, The Story of the Latter-day Saints, Salt Lake City 1992, s. 439. W Afryce pierwsi misjonarze pojawili się w 1960 roku w Nigerii, a następnie w Ghanie w 1962 roku. Op. cit., s. 611, 613. Rozmiar zmian, które nastąpiły między rokiem 1950 a 1990 odzwierciedlają dane dotyczące Kościoła. W 1950 r. ilość członków Kościoła wynosiła około 1100000 osób. Kościół posiadał 43 zorganizowane placówki misyjne w mniej niż 50 krajach, gdzie służyło około 6000 misjonarzy. W 1990 roku liczba członków wzrosła do 7300 000. Kościół posiadał 228 placówek misyjnych w 128 krajach, gdzie służyło około 40000 misjonarzy. Należy również podkreślić, że w 1950 r. około 7,7\% 
Misjonarze Kościoła Jezusa Chrystusa Świętych w Dniach Ostatnich dosyć wcześnie zainteresowali się terenami dzisiejszej Polski. Pierwsze notatki o dotarciu na te tereny pochodzą z końca XIX oraz początku $\mathrm{XX}$ wieku, kiedy to Polska znajdowała się pod zaborami lub tuż po wyzwoleniu - w okresie dwudziestolecia międzywojennego. W obydwu przypadkach miejscowości, w których można było spotkać wyznawców Kościoła, nie mieściły się w ówczesnych granicach Polski. Z materiałów udostępnionych przez Kościół wynika, że jednostki Kościoła istniały w Żarach (ówczesne Sorau) już w 1892 r., Królewcu (Königsberg), Szczecinie (Stettin), Wrocławiu (Breslau) w 1897 r., Kostrzynie (Küstrin) oraz Gdańsku (Danzig) będącym wówczas Wolnym Miastem oraz w Stargardzie (Stargard) w 1924 r., a w Gorzowie Wielkopolskim (Landsberg) i Pile (Schneidemühl) w 1930 r. Liczba członków Kościoła nie była zbyt duża i do wybuchu drugiej wojny światowej nie przekraczała 700 osób w danym okręgu ${ }^{12}$. Wyżej wymienione ośrodki nie należały do Misji Polskiej, lecz do 1924 r. do Misji Szwajcarsko-Niemieckiej, a od 1925 r. do Misji Niemiecko-Austriackiej ${ }^{13}$. Ważne jest podkreślenie tego faktu, ponieważ

populacji Kościoła żyło poza granicami USA, a w 1990 r. procent ten wzrósł do 40,5. Op. cit., s. 560, 561. Obecnie w 2007 roku Kościół jest obecny w 162 krajach, gdzie działa ok. 60000 misjonarzy. Liczy ok. 12 milionów wyznawców, z czego ponad połowa mieszka poza granicami USA. Oficjalna strona internetowa Kościoła Jezusa Chrystusa Świętych w Dniach Ostatnich: www.mormoni.pl.

12 Pierwsza Polka - pani Chalewa - została ochrzczona 2 lutego 1884 roku w Wiedniu. Wiliam Hartley, listopad 1982 r., Missionary's Two Months in Jail, „New Era", s. 8-12. W 1892 r. przybył do Żar David Hoagland Cannon - syn ówczesnego Pierwszego Doradcy Pierwszej Prezydencji. W następnym roku ochrzczono tam 37 osób, a w 1897 roku liczba członków zwiększyła się do 67 osób. G. W. Scharffs, Mormonism in Germany: A History of The Church of Jesus Christ of Latter-day Saints in Germany Between 1840 and 1970, w: H. W. Hunter, Eleanor Knowles, Salt Lake City 1994, http://search.ldslibrary.com/2735106. W 1923 roku w okręgu Królewca było 684 osób. W 1930 roku ta liczba zmalała do 610 osób, w tym 91 dzieci. W 1930 roku do okręgu szczecińskiego należało 541 osób, włączając 61 dzieci. W 1930 roku było na Mazurach już 287 członków, włączając w to 46 dzieci. W Pile w tym samym roku było 300 wyznawców, w tym 72 dzieci, a we Wrocławiu 685 członków, w tym 72 dzieci. Dane statystyczne dostarczone przez Kościół Jezusa Chrystusa Świętych w Dniach Ostatnich.

13 Do 1914 roku misjonarze oraz wyznawcy Kościoła Jezusa Chrystusa Świętych w Dniach Ostatnich w Austrii działający pod nazwą Stowarzyszenia Chrześcijańskiego (Christian Society) doświadczyli nieprzychylnego stosunku rządu austriackiego do ich wyznania. Jednostki Kościoła zostały rozwiązane, a ich majątek skonfiskowany. Założenie jednostek Kościoła po 1919 r. było możliwe dzięki traktatowi pokojowemu 
ta właśnie przynależność oraz niemieckie pochodzenie nawracających misjonarzy miały między innymi wpływ na stosunek mieszkańców obecnych terenów Polski do wyznawców tego Kościoła. Sytuacja stała się szczególnie napięta po zakończeniu drugiej wojny światowej, kiedy to traktowani jako ludność pochodzenia niemieckiego Mormoni doświadczyli prześladowań i większość z nich zdecydowała się opuścić te tereny.

Jednostką Kościoła, która najdłużej przetrwała w powojennej Polsce, była wieś Zełwagi w pobliżu Mikołajek na Mazurach (ówczesne Selbongen należące do Prus Wschodnich), do której religia Mormonów dotarła w 1922 roku. Religię tę zapoczątkował w tym miejscu mieszkaniec wsi Zełwagi - Fritz Fischer, który przyjął wiarę Joseph'a Smith'a podczas swojego pobytu w Berlinie. Jego działalność okazała się na tyle owocna, że po kilku latach tzn. w 1929 roku założono tam pierwszą w Niemczech kaplicę, a większość mieszkańców wsi deklarowała właśnie przynależność do Kościoła Jezusa Chrystusa Świętych w Dniach Ostatnich, co stanowiło unikalne zjawisko w ówczesnej Europie ${ }^{14}$.

Po zakończeniu drugiej wojny światowej, wiele kościołów protestanckich, w szczególności tych na terenach poniemieckich, znalazło się w trudnej sytuacji. Ich mienie zostało zniszczone, a liczba wyznawców znacznie uszczuplona. Tereny Prus Wschodnich oraz Niemiec, gdzie znajdowały się miejscowości, w których praktykowano religię Kościoła Jezusa Chrystusa Świętych w Dniach Ostatnich zostały przekazane Polsce. Sytuacja na tych terenach była na tyle niekorzystna dla Mormonów, których utożsamiano z „niemieckimi najeźdźcami”, że musieli oni opuścić zamieszkiwane dotąd tereny. W 1958 roku rząd Polski „udzielił zgody na wyjazd wszystkim Niemcom, którzy dobrowolnie pozostali w Polsce po wojnie i tu zamieszkali, a chcieli jednak w czasach komunizmu ją opuścić"15. Jedyną funkcjonującą jednostką Kościoła w Polsce pozostawała właśnie wieś Zełwągi, której mieszkańcy pomimo licznych prześladowań ze stro-

w Wersalu (1919 r.) gwarantującemu wolność religijną. F. Walter, June 1923, The Chuch in Vienna Austria, „Improvement Era” 1923, vol. XXVI, no. 8, http://search.ldslibrary.com/1681811.

14 „Zrób coś dobrego w Boże Narodzenie”, http://www.mormoni.pl/dl/zelwagi_2005_raport.pdf. W 1971 r. Erich Koenietz zrzekł się użytkowania kaplicy w imieniu Kościoła Jezusa Chrystusa Świętych w Dniach Ostatnich. Protokół Zdawczo-Odbiorczy Prezydium Wojewódzkiej Rady Narodowej w Olsztynie z dnia 28 czerwca $1971 \mathrm{r}$. Materiały źródłowe dostarczone przez Kościół.

15 A. Leśniewski, Mormoni-Amerykański Wynalazek Religijny, Maternus Media 2001, s. 46. 
ny zarówno ludności polskiej, jak i ze strony Rosjan, starali się integrować ze społeczeństwem polskim. Jednakże również tutaj „trudności napotykane przez Mazurów, poczucie wyobcowania oraz otwierające się możliwości emigracji do Niemiec spowodowały stopniowy spadek liczby członków Kościoła" ${ }^{\text {"16 }}$ W 1967 roku ta misja liczyła już jedynie 24 wyznawców ${ }^{17}$. Oficjalnie została ona zamknięta w 1971 roku, a ostatni wyznawcy opuścili te tereny na początku lat osiemdziesiątych ${ }^{18}$.

Po drugiej wojnie światowej niewiele wydarzyło się w historii Mormonów w Polsce. Po intensywnych negocjacjach prowadzonych w latach 40-tych XX wieku, podczas których przedstawiciele Kościoła próbowali oficjalnie zarejestrować swoje wyznanie, zostali oni zapewnieni o przyjaznym nastawieniu rządu polskiego do działalności misjonarskiej Kościoła w Polsce oraz o wolności religijnej panującej w tym kraju ${ }^{19}$. W 1946 roku Ezra Taft Benson spotkał się z ówczesnym Ministrem Sprawiedliwości Henrykiem Świątkowskim oraz w Warszawie ze Stanisławem Mikołajczykiem - premierem RP na Uchodźstwie, który zapewnił go o gotowości współpracy w przypadku chęci założenia misji Kościoła w Polsce ${ }^{20}$. Jednakże ze względu na trudną sytuację polityczną w Polsce rejestracja Kościoła nie doszła do skutku, bowiem lata 1947 oraz 1948 przyniosły zmiany w stosunku nowych władz do wyznań nierzymskokatolickich. „Nastąpił odwrót od pewnego liberalizmu i otwartości, załatwiania spraw zgodnie z artykułami konstytucji marcowej czy przedwojennymi aktami prawnymi, które regulowały status Kościołów”21. Zaniechano również uregulowania statusu wyznań, których sytuacja prawna przed drugą wojną światową nie została unormowana. Dopiero w 1949 roku uchwalono nowe prawo o stowarzyszeniach, które umożliwiało rejestrację wyznań

${ }^{16}$ Zrób coś dobrego w Boże Narodzenie, http://www.mormoni.pl/dl/zelwagi_2005_raport.pdf.

${ }_{17}$ Knowles Eleanor, Howard W. Hunter, http://search.ldslibrary.com/2735579.

18 L. M. Szwengrub, 1962, Mormoni w powiecie olsztyńskim, „Euhemer - Przegląd Religioznawczy", s. 62-64; Zrób coś dobrego w Boże Narodzenie, http://www.mormoni.pl/dl/zelwagi_2005_raport.pdf.

19 F. Babbel, pażdziernik 1946, Europe's Valiant Saints Forge Ahead, „Improvement Era" 1946, vol. XIIX, no. 10, http://search.ldslibrary.com/1988669.

20 Ezra Taft Benson, Labor of Love, Salt Lake City 1989, http://search.ldslibrary.com/2472292; Ezra Taft Benson, First Day-Morning Meeting, Conference Papers 1962, http://search.ldslibrary.com/116564.

${ }^{21}$ B. Polak, Marzec 2004, Zwalczani i koncesjonowani. O Mniejszościach wyznaniowych w PRL, „Biuletyn Instytutu Pamięci Narodowej”, nr 3 (48), s. 8. 
o nieuregulowanym do tamtej pory statusie prawnym. Jednakże z powodu selektywnej polityki państwa wobec poszczególnych wyznań oraz niedostatecznego rozpowszechnienia informacji o znowelizowanym prawie, tylko kilkanaście z nich skorzystało z możliwości zarejestrowania się w tym czasie ${ }^{22}$. Dopiero po 1956 roku, kiedy władze doszły do wniosku, „że w walce z religią i jej przedstawicielami należy skupić się na Kościele rzymskokatolickim"23, nastapiła liberalizacja polityki wyznaniowej. Pozwoliło to w 1961 roku na rejestrację Kościoła Jezusa Chrystusa Świętych w Dniach Ostatnich w woj. olsztyńskim jako stowarzyszenia wyznaniowego z siedzibą w Zełwagach. Liczba wyznawców w tym roku wynosiła 46 osób $^{24}$. Kolejną ważną datą $\mathrm{w}$ historii Kościoła w Polsce był dzień 30 maja 1977 r., kiedy to Kościół Jezusa Chrystusa Świętych w Dniach Ostatnich został zarejestrowany w Urzędzie do Spraw Wyznań jako oficjalnie działające wyznanie. Wydarzeniu temu towarzyszyła wizyta Spencer'a Kimball'a - ówczesnego Prezydenta Kościoła.

Działalność Mormonów była w latach powojennych dosyć ograniczona ze względu na fakt, iż z jednej strony, większość Polaków była religijna, zdominowana przez wyznanie rzymskokatolickie oraz negatywnie nastawiona do nowych ruchów religijnych, a z drugiej strony, ze względu na politykę komunistycznego państwa, jakim wówczas była Polska, wobec religii. Sami Misjonarze podkreślali, iż trudno jest prowadzić działalność na terenach, gdzie z jednej strony próbuje się utworzyć państwo ateistyczne, gdzie religia traktowana jest jak opium dla społeczeństwa, a z drugiej strony Chrystusa zastępuje się Leninem ${ }^{25}$. Jednakże pomimo braku oficjalnej siedziby Kościoła Jezusa Chrystusa Świętych w Dniach Ostatnich na szczeblu ogólnonarodowym w Polsce oraz pomimo utrudnień związanych z biurokracją, uzyskaniem wiz oraz niechętnym nastawieniem rządu do cudzoziemców z Zachodniej Europy tudzież Stanów Zjednoczonych, pojedynczy wyznawcy byli odwiedzani przez wysokich

22 B. Polak, Zwalczani $i$ koncesjonowani. O Mniejszościach wyznaniowych w PRL, s. 8, 9 .

23 B. Polak. Marzec 2004, Dziel i Rzq̨dź. O Polityce Rzqdu PRL wobec Kościołów Protestanckich, „Biuletyn Instytutu Pamięci Narodowej”, nr 3 (48), s. 26.

24 Statut Kościoła Jezusa Chrystusa Świętych w Dniach Ostatnich z 1961 r. Materiały źródłowe dostarczone przez Kościół.

25 W. Lenin, O Stosunku Partii Robotniczej do Religii, http://www.marxists.org/polski/lenin/1909/05/o_st_par.htm; A. Gaeth, luty 1937, Nations that Need the Gospel but Have It Not, „Improvement Era” 1937, vol. XI, no. 2, http://search.ldslibrary.com/1858839. 
rangą dostojników kościelnych. W 1947 oraz 1959 roku wizytę w Polsce złożył Ezra Taft Benson - późniejszy Prezydent Kościoła oraz Minister Rolnictwa w rządzie Prezydenta Eisenhower'a ${ }^{26}$. W czasach powojennych Polskę odwiedzali również przedstawiciele misji ze Szwajcarii ${ }^{27}$.

Obecnie w Polsce wolność wyznania gwarantuje Konstytucja Rzeczypospolitej Polski uchwalona 2 kwietnia 1997 roku (artykuł 25 oraz 53) oraz Ustawa z dnia 17 maja 1989 r. o gwarancji wolności sumienia i wyznania, znowelizowana nieznacznie w 2004 roku. Kościół Jezusa Chrystusa Świętych w Dniach Ostatnich został wpisany w dniu 11 stycznia 1990 roku do Rejestru Kościołów oraz Innych Związków Wyznaniowych, które nadzoruje Ministerstwo Spraw Wewnętrznych i Administracji. Pierwszym Prezydentem Kościoła został Walter Whipple. W Polsce obecnie znajduje się około 1500 wyznawców Kościoła Jezusa Chrystusa Świętych w Dniach Ostatnich. Liczba ta nie prezentuje się zbyt imponująco, zwłaszcza że na 38,2 milionów mieszkańców w 2004 roku Kościół katolicki liczył 34,4 miliona ochrzczonych ${ }^{28}$. Kościół Mormonów znalazł się za takimi wyznaniami jak: Polski Autokefaliczny Kościół Prawosławny (508,7 tys. osób), Świadkowie Jehowy (124,3 tys. wyznawców), Kościół Ewangelicko-Augsburski (79 tys. osób), Kościół Starokatolicki Mariawitów (24,1 tys.), Kościół Zielonoświątkowy (20,3 tys.), Kościół Adwentystów Dnia Siódmego (9,5 tys.), Kościół Ewangelicko-Metodystyczny $\left(4,4\right.$ tys.) oraz Muzułmański Związek Religijny (5,1 tys.) ${ }^{29}$. Gminy Kościoła znajdują się w kilku miastach Polski: Warszawie, Łodzi, Poznaniu, Wrocławiu, Katowicach, Lublinie, Krakowie, Gdańsku, Bydgoszczy oraz Białymstoku.

26 Sheri L. Dew, Ezra Taft Benson, A Biography, Salt Lake City 1987, http://search.ldslibrary.com/2732121. Materiały dostarczone przez Kościół Jezusa Chrystusa Świętych w Dniach Ostatnich.

27 W 1967 roku wieś Zełwagi została odwiedzona przez Howard'a Hunter'a - Prezydenta Kościoła Jezusa Chrystusa Świętych w Dniach Ostatnich w latach 1994-1995 - oraz przez Rendell'a Mabey’a - Prezydenta Misji w Szwajcarii. Wówczas ta jednostka Kościoła w Polsce, której Prezydentem był Erach Konietz - liczyła jedynie 24 osoby. Przedstawiciele kościoła odwiedzili również Gliwice, gdzie mieszkały dwie wyznawczynie tej religii. Eleanor Knowles, Howard W. Hunter, Salt Lake City 1994, http://search.ldslibrary.com/2734775.

${ }_{28}$ Polska w Latach 1946-2005, http://www.stat.gov.pl/opracowania_zbiorcze/duzy_rocznik_stat/2006/drs2006-wazniejsze_dane_kraju.pdf.

${ }^{29}$ Kościoły $i \bar{W}$ yznania $w$ liczbach - nowe $\bar{d}$ ane $\bar{G} U S$, Warszawa, 4 luty 2004, http://ekai.pl/serwis/?print=1\&MID=6731. 
Przytoczone powyżej dane oznaczają, że w ciagu kilkunastu lat swojej działalności przedstawiciele Kościoła napotykali na wiele trudności związanych z przekonaniem zdominowanych przez religię katolicką Polaków o prawdziwości swoich wierzeń. Czy uda się w Polsce powtórzyć sukces odniesiony przez założycieli Kościoła w USA? Wiele czynników wskazuje na to, iż Kościół Jezusa Chrystusa nie znajdzie się na dominującej pozycji wśród wyznań Polski. Dlaczego? Otóż brak tradycji pluralizmu religijnego w Polsce, homogeniczność społeczeństwa polskiego, automatyczne przechodzenie kolejnych pokoleń na religię rzymskokatolicką oraz nieufność wobec odmiennych wyznań, jak również, w przypadku Mormonów, dystans dzielący Polskę i USA, ograniczają możliwości odniesienia sukcesu na rywalizacji religijnej w Polsce.

\section{Summary}

Is Poland open to new religions? The answer to this question is a complex one. From the legal point of view every denomination or religion is guaranteed equality. However, when we consider that $90 \%$ of Poles are Roman Catholics (at least in statistics), we should note that Catholicism decidedly prevails and the remaining denominations are far from popular. Reaching back in history to the year 966, the Catholic faith has become a part of Polish culture over the centuries. Irrespective of the schisms the Church has experienced in the West, it has remained rather homogeneous in Poland. Yet its strong position has not hindered the representatives of other denominations in reaching Polish territories and winning over believers. 